\title{
The interrelationships of pancreatic enzymes in human duodenal aspirate ${ }^{1}$
}

\author{
D. M. GOLDBERG AND K. G. WORMSLEY
}

From the Royal Hospital and Royal Infirmary, Sheffield

SUMMARY The interrelationships of proteolytic enzymes and amylase have been studied in the duodenal aspirate obtained from subjects with normal and abnormal pancreatic function during stimulation with secretin and pancreozymin. While the relationship of trypsin to chymotrypsin was independent of stimulus and presence of pancreatic disease the ratio of proteolytic enzymes to amylase rose when the degree of stimulation of the pancreas was increased. Patients with recent acute pancreatitis and with chronic pancreatitis tended to have more severe impairment of secretion of proteolytic enzymes than of amylase. In routine tests of pancreatic function both proteolytic and non-proteolytic enzymes should be measured, both because an abnormal ratio may be of diagnostic significance and because the two different groups of enzymes provide mutual checks of the secretory capacity of pancreatic enzymes.

Since the secretion of digestive enzymes is a function of the pancreas, estimation of enzyme secretory capacity provides an important and specific index of the state of the pancreatic secretory cells. However, there is no unanimity about the type and number of pancreatic enzymes which must be estimated in order to provide a satisfactory criterion of the secretory capacity of pancreatic enzymes. In the present study, we have investigated the interrelationships among some of the pancreatic enzymes in the duodenal aspirate obtained during tests of pancreatic function in order to determine the most satisfactory measure for routine investigational use.

\section{Methods}

The subjects of the present study comprised 16 healthy normal individuals (eight medical students and eight patients without alimentary complaints,

1Please address any requests for reprints to $\mathbf{K}$. G. Wormsley, Clinical Investigation Unit, Maryfield Hospital, Dundee DD4 7TL.

Received for publication 13 April 1970. with inguinal hernia or varicose veins); 20 patients with chronic duodenal ulcer; 13 patients who were tested either between three and six weeks or more than four months after attacks of acute pancreatitis; 10 patients with chronic pancreatitis; seven patients with anicteric pancreatic carcinoma. All subjects were taking normal diets at the time of their tests. In each subject, one or more enzymes were estimated in duplicate or by more than one method.

Techniques of intubation have been described previously (Wormsley, 1968). Amylase was estimated using the methods of Norby (Lagerlöf, 1942) and of Bernfeld (Bernfeld and StuderPécha, 1947); proteolytic activity by the method of Gowenlock (1953); trypsin and chymotrypsin by the titrimetric method of Haverback, Dyce, Gutentag, and Montgomery (1963) using tosyl arginine methyl ester as substrate for trypsin, and acetyl tyrosine ethyl ester as substrate for chymotrypsin. Enzyme estimations were carried out within two to three days of the test on duodenal aspirate which had been diluted with an equal volume of glycerol and kept frozen $\left(-20^{\circ} \mathrm{C}\right)$. The stability of random samples was tested over the course of one month.

Each subject had two tests, during which pan- 
creatic secretion was stimulated by continuous intravenous infusion of secretin $(0.25$ or 2.0 $\mathrm{CU} / \mathrm{kg}$-hour), or a combination of secretin (0.25 CU/kg-hour) plus pancreozymin (16 CHR $\mathrm{U} / \mathrm{kg}$-hour). The hormones were obtained from the GIH Laboratory, Karolinska Institute, Stockholm, Sweden. Each test lasted 50 minutes, excepting five studies which were continued for two hours. Two to three weeks were allowed to elapse between tests.

The values of enzyme activity have been expressed as concentrations of individual 10minute samples or as mean concentrations of pooled samples comprising the duodenal aspirate secreted during the whole test or during the final 30 minutes of each test. The significance of the differences in the distribution of the ratios of the enzymes to each other has been assessed by means of the Mann-Whitney ' $U$ ' test (Siegel, 1956).

\section{Results}

\section{REPRODU CIBILITY}

The reproducibility of all methods was very good (Figs. 1 and 2). There was no decrease in the activity of the measured enzymes during the course of one month. The errors in the titrimetric method of estimating trypsin and chymotrypsin have been described previously (Goldberg, Campbell, and Roy, 1969).

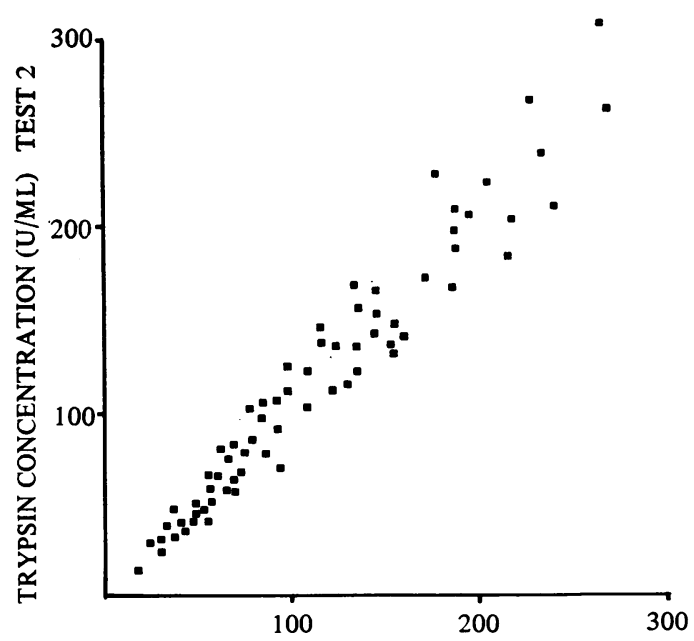

TRYPSIN CONCENTRATION (U/ML) TEST 1

Fig. 1 Reproducibility of the measurement of proteolytic activity (Gowenlock method). Each point represents duplicate estimations on one sample of duodenal aspirate (denoted by 'Test 1' and 'Test 2' respectively).
CORRELATION BETWEEN THE DIFFERENT METHODS OF MEASUREMENT

The correlation between the two methods of measuring amylase was excellent (Fig. 3). Agreement between total proteolytic activity (Gowen- $\stackrel{-5}{+}$ lock method) and trypsin concentration (Haver-o back method) was similarly good (Fig. 4).

\section{CORRELATION BETWEEN TRYPSIN AND}

CHYMOTRYPSIN

The correlation between trypsin (Haverback et al,$\stackrel{\vec{\circ}}{-}$ 1963) and chymotrypsin was excellent and inde- $\vec{\omega}$ pendent of stimulant or the condition of the pancreas (Fig. 5). The ratio of trypsin to chymotrypsin ranged from 1.5 to 3.0 in different subjects with normal pancreas, but not by more than $0.5_{-}^{-}$ within this range in the same individual under? different conditions of stimulation or duringe duplicate tests. Although the range of ratios was considerably greater in patients with pancreatic disease $(0.8$ to 4.6$)$ the difference from normal was not significant $(\mathrm{P}>0 \cdot 3)$.

OUTPUTS OF PROTEOLYTIC ENZYMES AND OF AMYLASE

Patients with pancreatic disease secreted less $\square$ proteolytic enzymes (Gowenlock method) than normal (Fig. 6) except some months after an acute attack of pancreatitis, when the secretiono of proteolytic enzymes had reverted within nor-市 mal limits (Table and Fig. 6). The pattern of

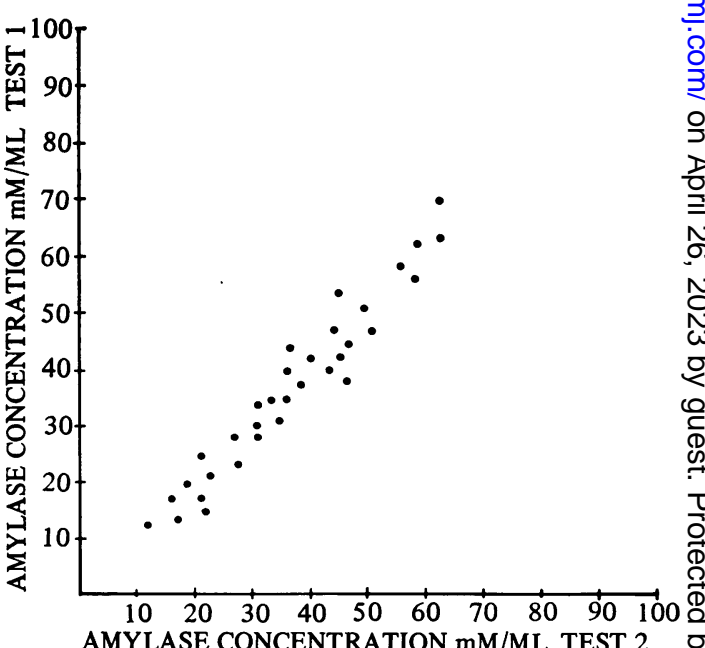

Fig. 2 Reproducibility of the measurement of amylase activity by the method of Bernfeld (significance of points as in Figure 1). 


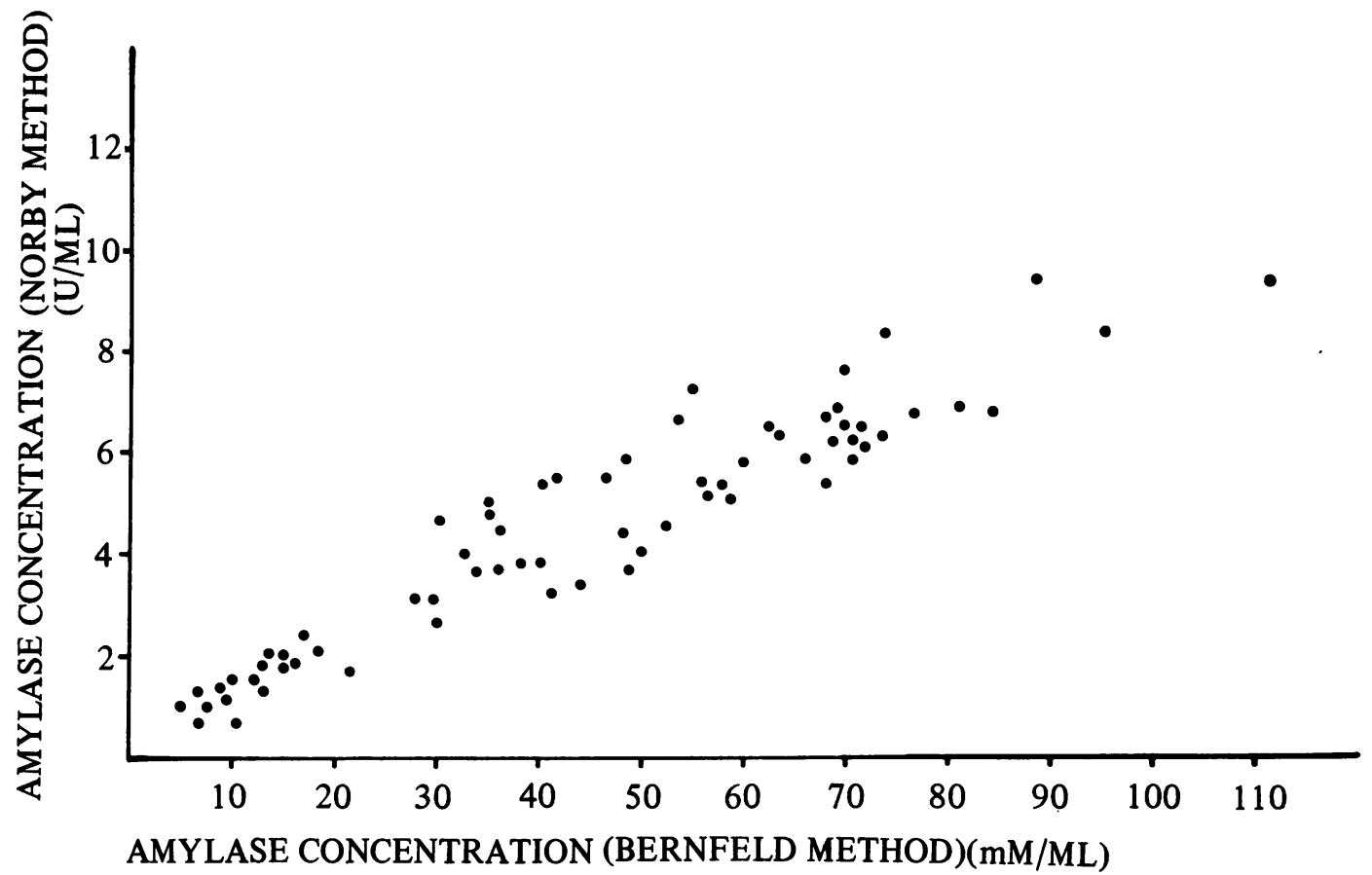

Fig. 3 Comparison of activity of amylase by the methods of Norby and Bernfeld. Each point denotes the two values of activity of one sample of duodenal aspirate.

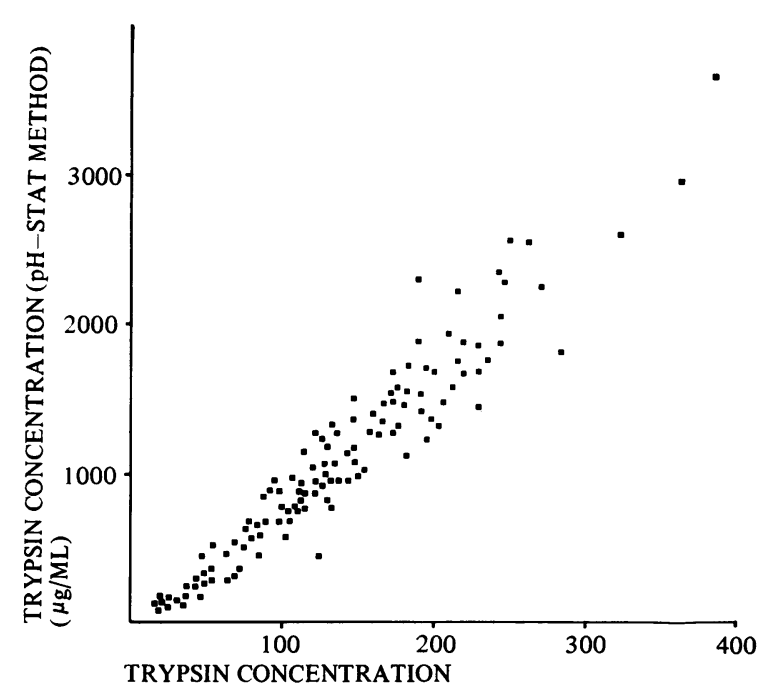

Fig. 4 Comparison of the proteolytic activity (Gowenlock method) and tryptic activity $(\mathrm{pH}$ stat method of Haverback). Each point denotes the two values of activity of one sample of duodenal aspirate.
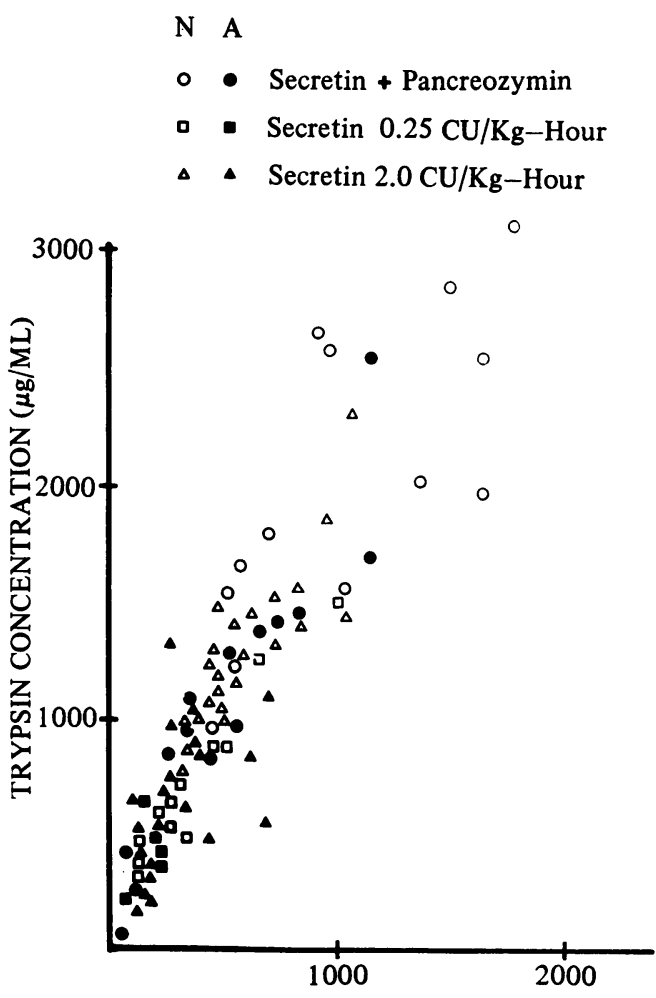

CHYMOTRYPSIN CONCENTRATION( $\mu \mathrm{g} / \mathrm{ML})$

Fig. 5 Correlation between concentrations of trypsin and chymotrypsin. Each point represents the values of one sample of duodenal aspirate. $\mathrm{N}=$ aspirate from subjects with normal pancreas; $\mathbf{A}=$ aspirate from patients with abnormal pancreas. 


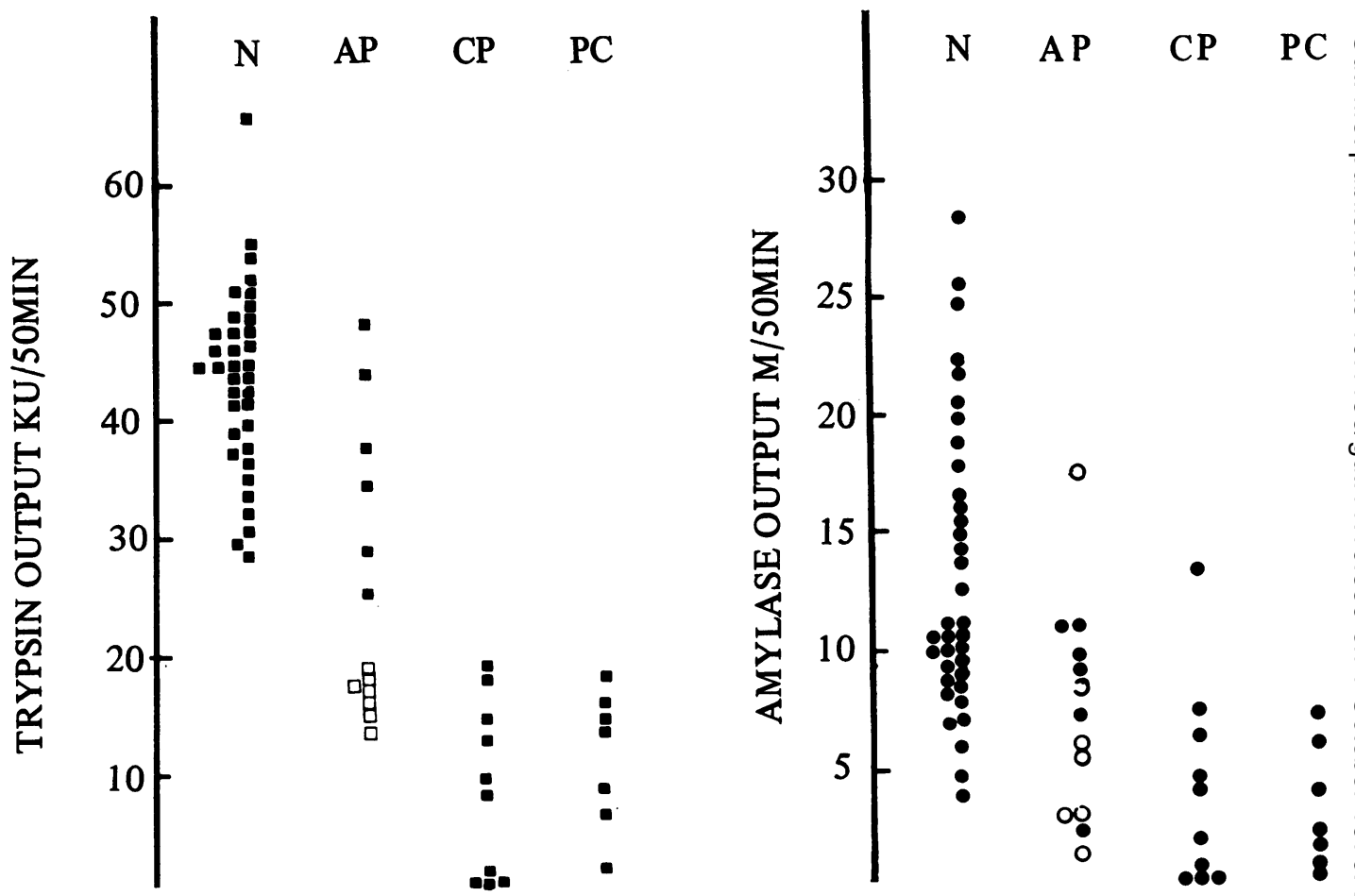

Fig. 6 Outputs of proteolytic activity (trypsin and amylase) during 50-minute infusions of secretin plus pancreozymin. $\mathrm{N}=$ normal and duodenal ulcer subjects; $\mathrm{AP}=$ acute pancreatitis; $\mathrm{CP}=$ chronic pancreatitis; PC = pancreatic carcinoma. The open symbols represent results from patients tested within six weeks of an acute attack; the closed symbols, tests more than four months after an attack of acute pancreatitis.
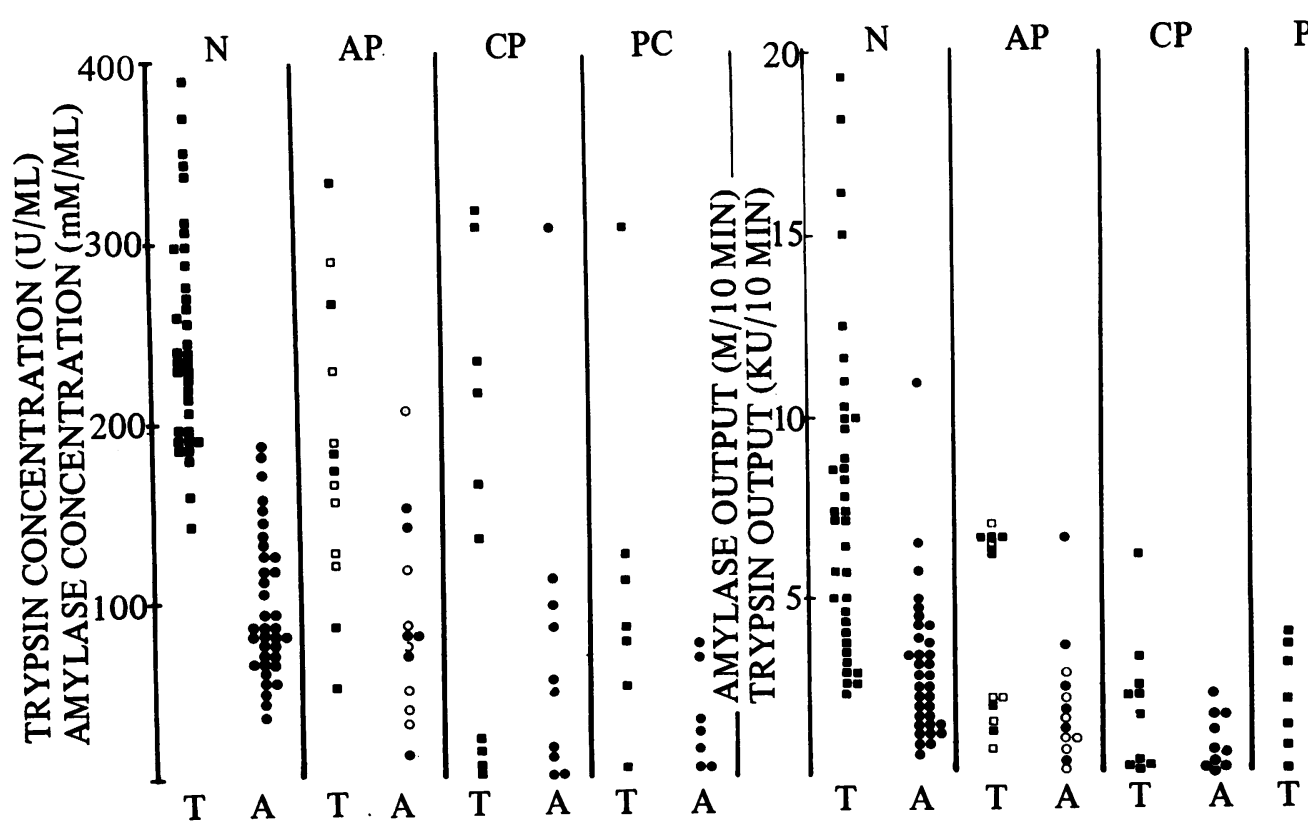

Fig. 7 Concentrations and outputs of proteolytic activity (trypsin and amylase) during the first 10 minutes of tests depicted in Figure 6.

$\mathbf{T}=$ trypsin $; \mathbf{A}=$ amylase. 
The interrelationships of pancreatic enzymes in human duodenal aspirate

\begin{tabular}{|c|c|c|c|c|c|c|}
\hline Patient & $\begin{array}{l}\text { Trypsin }{ }^{1} \\
(K U / 50 \text { min })\end{array}$ & $\begin{array}{l}\text { Amylase } \\
(M / 50 \text { min })\end{array}$ & $\begin{array}{l}\text { Ratio of Trypsin } \\
\text { to Amylase }\end{array}$ & $\begin{array}{l}\text { Trypsin } \\
(K U / 50 \text { min })\end{array}$ & $\begin{array}{l}\text { Amylase } \\
(M / 50 \mathrm{~min})\end{array}$ & $\begin{array}{l}\text { Ratio of Trypsin } \\
\text { to Amylase }\end{array}$ \\
\hline $\begin{array}{l}1 \\
2 \\
3 \\
4 \\
5\end{array}$ & $\begin{array}{l}14.9 \\
13 \cdot 2 \\
19 \cdot 1 \\
16 \cdot 0 \\
17 \cdot 4\end{array}$ & $\begin{array}{r}5.5 \\
8.5 \\
2.8 \\
16.5 \\
2.6\end{array}$ & $\begin{array}{l}2 \cdot 71 \\
1 \cdot 54 \\
6 \cdot 73 \\
0 \cdot 97 \\
6 \cdot 70\end{array}$ & $\begin{array}{l}33.0 \\
33.6 \\
33.9 \\
48 \cdot 1 \\
36.8\end{array}$ & $\begin{array}{r}8 \cdot 9 \\
8 \cdot 6 \\
8 \cdot 6 \\
9 \cdot 7 \\
18 \cdot 7\end{array}$ & $\begin{array}{l}3.71 \\
3.93 \\
3.96 \\
4.96 \\
1.97\end{array}$ \\
\hline
\end{tabular}

Table Serial responses of patients after attacks of acute pancreatitis $(0 \cdot 25 \mathrm{CU} / \mathrm{kg}$-hour secretin + $16 \mathrm{CHR}$ U/kg-hour pancreozymin)

${ }^{1}$ Estimated by the method of Gowenlock (1953).

${ }^{2}$ Estimated by the method of Bernfeld (Bernfeld and Studer-Pécha, 1947).

normal values of amylase output (Bernfeld method) showed a distribution which was skew towards the lower end of the range, so that there was some overlap between the amylase outputs of normal subjects and of patients with pancreatic disease (Fig. 6). There was considerable overlap between the outputs of proteolytic enzymes and of amylase during the first 10 minutes of the tests in normal subjects and in patients with pancreatic disease (Fig. 7) but the differences were significant $(\mathrm{P}<0.001)$.

\section{CORRELATION BETWEEN PROTEOLYTIC}

ACTIVITY AND AMYLASE

There was no simple relationship between proteolytic activity (Gowenlock method) and the

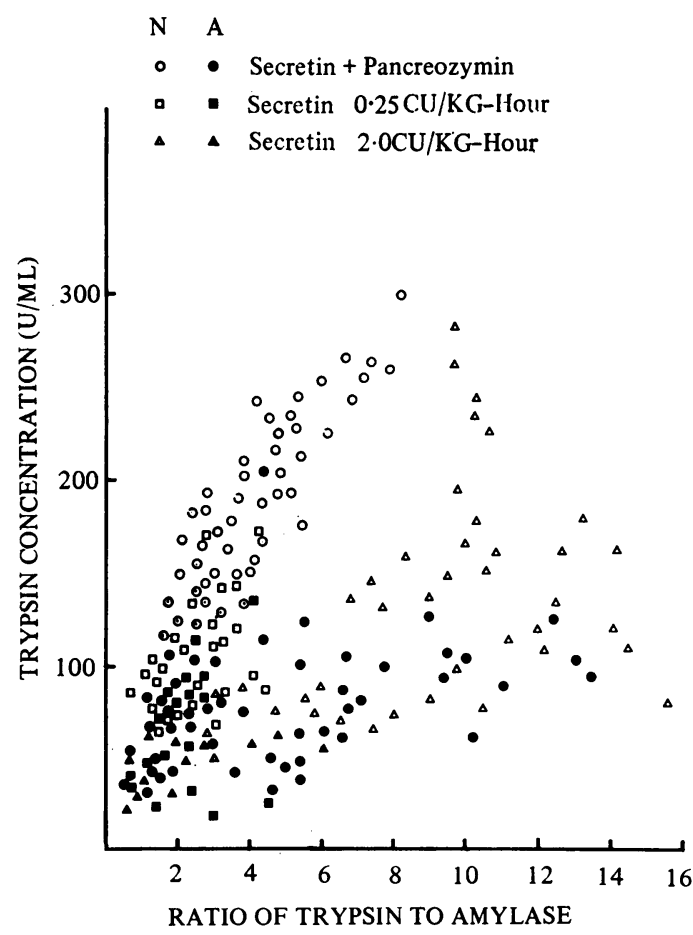

Fig. 8 Relationship between the ratio of proteolytic activity (trypsin to amylase) in duodenal aspirate and the concentration of proteolytic enzymes (symbols as in Figure 5). concentration of amylase(Bernfeld method) in the duodenal contents obtained during different conditions of stimulation and in different groups of individuals. For the purpose of presentation, the results from each individual have therefore been expressed as the ratio of proteolytic activity to the concentration of amylase during each test.

The ratio of proteolytic activity to amylase increased with an increase in the concentration or output of proteolytic enzymes (Figs. 8 and 9). The ratio was also dependent on the type of stimulus, being lowest with the low dose rates of secretin, significantly greater $(P<0.001)$ when pancreozymin was added, and highest $(\mathrm{P}<0.001)$ with the high dose rates of secretin (Figs. 8, 9, and 10). The ratio of proteolytic enzymes to amylase did not change during two-hour infusions of secretin (Fig. 11). The ratio of proteolytic activity to amylase was not different $(P>0.4)$ between normal subjects and patients with duodenal ulcer, and these two groups have therefore been taken together for the purpose of calculation and illustration. The abnormal ratio of proteolytic activity to amylase of patients after an attack of acute pancreatitis returned to normal within six months, when enzyme secretory capacity reverted to normal (Table). The ratio of proteolytic activity to amylase tended to be low in patients with acute and chronic pancreatitis and pancreatic carcinoma (Fig. 10).

\section{Discussion}

The results of the present study have shown that the techniques used for estimating the activity of the proteolytic enzymes and of amylase give reproducible results. The relationship of the two proteolytic enzymes (trypsin and chymotrypsin) to each other was not dependent on the magnitude of the enzyme output, type of secretory stimulus, or pancreatic disease. Good correlation between trypsin and chymotrypsin in duodenal aspirate had been recorded previously (Zieve, Silvis, Mulford, and Blackwood, 1966; Ribet, Pascal, and Vaysse, 1968) under experimental conditions which differed from those used in the present study, although Rothman (1967) had noted that pancreozymin stimulated the secretion 


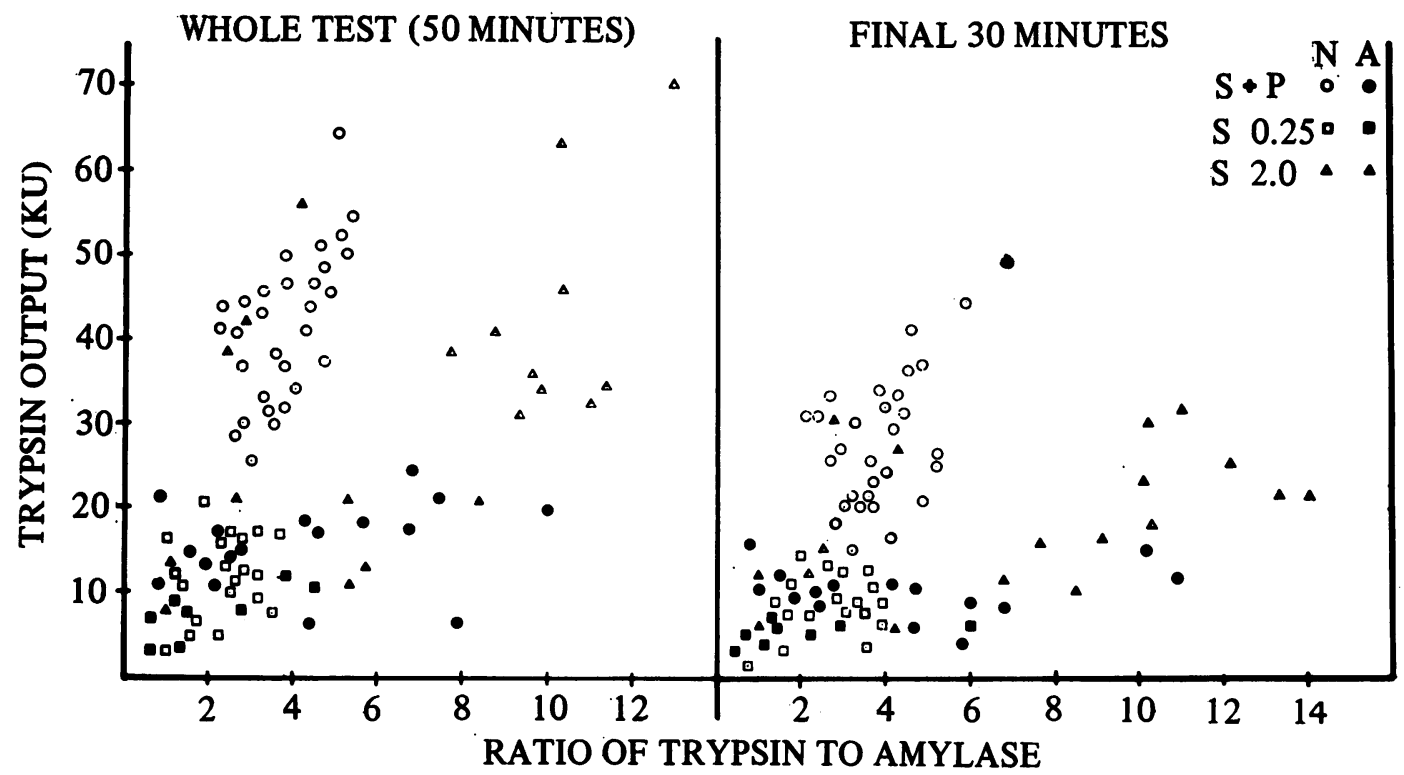

Fig. 9 Relationship between the ratio of proteolytic activity (trypsin to amylase) in duodenal aspirate and the output of proteolytic enzymes in response to 50-minute infusions or during the final 30 minutes of each infusion. $\mathrm{N}$ and $\mathrm{A}$ as in Fig. $5 . \mathrm{S}=$ secretin 0.25 or $2.0 \mathrm{CU} / \mathrm{kg}$-hour; $\mathrm{S}+\mathrm{P}=\operatorname{secretin}(0.25 \mathrm{CU}$ per/kg-hour) + pancreozymin (16 CHR U/kg-hour).

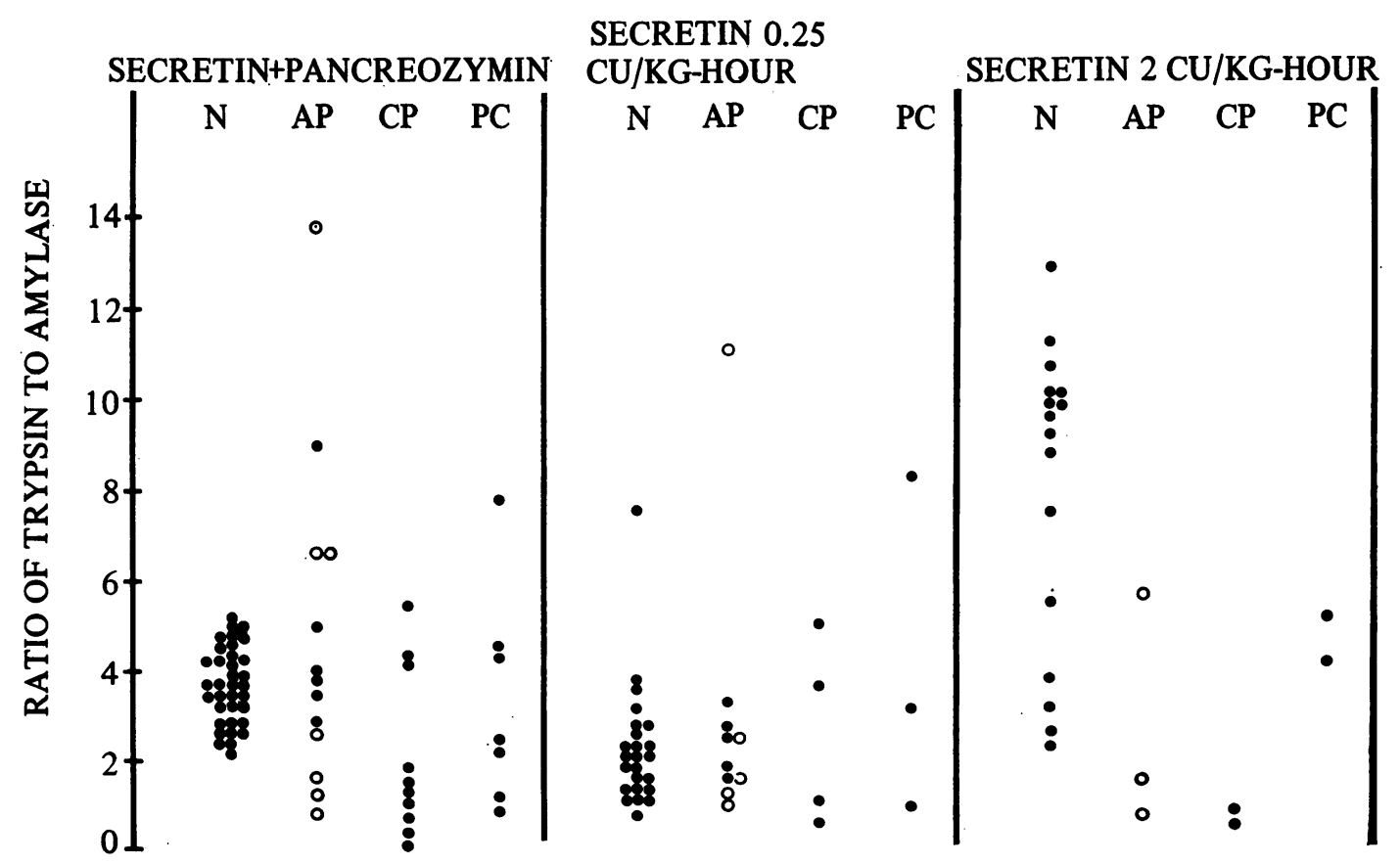

Fig. 10 Range of ratios of proteolytic activity (trypsin to amylase) in health and disease. Each point represents the result from one subject in response to the 50-minute infusion indicated at the top of each of the three columns (symbols as in Figure 6). 


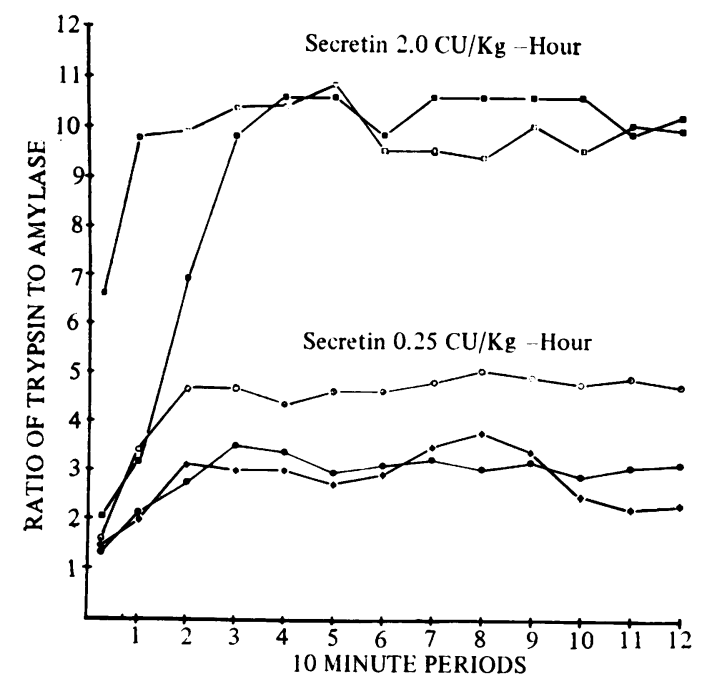

Fig. 11 Ratio of proteolytic activity (trypsin to amylase) during two-hour infusions of secretin $(0.25 \mathrm{CU} / \mathrm{kg}$-hour in three subjects and $2.0 \mathrm{CU} / \mathrm{kg}$ hour in two subjects). Each point represents the value of the ratio in the appropriate 10-minute sample of duodenal aspirate.

of trypsin, without parallel secretion of chymotrypsin, in an experimental preparation of isolated pancreas.

Most of the controversy about the interrelationships of human pancreatic enzymes has concerned the ratio of proteolytic enzymes to amylase (and to lipase). Lagerlöf (1942) noted a linear relationship between the concentration of trypsin and amylase after injection of secretin, confirming Babkin's hypothesis that pancreatic enzymes were secreted 'in parallel'. 'Parallel' secretion of pancreatic enzymes was also reported in response to injections of secretin (Burton, Evans, Harper, Howat, Oleesky, Scott, and Varley, 1960) and of pancreozymin (Burton et al, 1960; Creutzfeldt, 1964; Rick, 1965; Sarles, Figarella, Prezelin, and Souville, 1966; Ammann, Tagwercher, Kashiwagi, and Rosenmund, 1968). On the other hand, Guth, Komarov, Shay, and Style (1956) found statistically significant day-to-day deviations from 'parallelism' in the enzyme response to food in dogs, while Worning and Müllertz (1966) described considerable variation between the concentrations of different enzymes in response to test meals in man, mainly attributable to variation between individuals. Sarles et al (1966) noted that lipase disappeared from human duodenal contents during prolonged infusions of secretin, without change in the activities of the other enzymes, while sham feeding elicited a different type of dissociation, with marked stimulation of the secretion of lipase, less of trypsin, and virtually no change in the output of amylase. A further type of dissociation was described by Ribet et al (1968), who noted an increase in the ratio of trypsin to lipase when pancreozymin was added to an infusion of secretin, similar to the increase in the ratio of proteolytic enzymes to amylase in response to pancreozymin found in the present study. The secretion of pancreatic enzymes has also been found to deviate from 'parallelism' in patients with pancreatic disease. Lagerlöf (1939) suggested that in patients with acute pancreatitis the concentration of amylase might be abnormally low while trypsin remained within defined normal limits. Similar findings were reported in patients with other types of pancreatic disease (Burton et al, 1960) and it was suggested that amylase secretion was the most satisfactory index of pancreatic disease, since trypsin secretion could be normal in patients with pancreatic disorders. On the other hand, Hershfield, Lind, and Hildes (1968) found that isolated, defective secretion of amylase in response to injections of secretin and pancreozymin could not be considered a reliable indication of disease of the pancreas. Similarly, Gibbs (1950) showed that the secretion of amylase was sometimes grossly defective in normal infants, whose secretion of trypsin was normal, while Choi, Goldstein, Wirts, and Menduke (1967) recommended the measurement of trypsin because trypsin secretion could be abnormal when amylase secretion remained normal in patients with pancreatic disease. In a much earlier study, Diamond, Siegel, Gall, and Karlen (1939) had already suggested that the practice of estimating only one enzyme was not an adequate measure of total pancreatic capacity to secrete enzymes, because they found frequent dissociation between trypsin and amylase secretion.

The present study has shown that the relationship between amylase and proteolytic enzymes is not constant but can change markedly both in pancreatic disease and if the stimulus to secretion is changed by the addition of pancreozymin or by increasing the dose rate of secretin. It is possible that the change in the ratios of the enzymes in pancreatic disease is related, in part, to changes in food intake or absorption and to alteration in the relative availability of the basic constituents of food materials, since Grossman, Greengard, and Ivy (1942) and Ben Abdeljlil and Desnuelle (1964) have demonstrated that selective changes in the secretion of pancreatic enzymes could be brought about by experimental changes in the composition of the diet. Changes in nutrition could not explain the transient changes in the ratios of the pancreatic enzymes after attacks of acute pancreatitis, nor the changes elicited by different pancreatic stimulants.

The findings of the present study suggest that the output of proteolytic enzymes provides a better index of enzyme secretory capacity than does output of amylase, since the normal pancreas responds to increased stimulation with a greater increase in the secretion of proteolytic enzymes than of amylase. In addition, the secretion of proteolytic enzymes in response to pancreatic 
stimulants given by continuous intravenous infusion provides a satisfactory criterion for the separation of normal from abnormal pancreatic function. However, since the value of the ratio of proteolytic to non-proteolytic enzymes may be useful in the diagnosis of disease, it is preferable to measure both types of enzyme in routine clinical studies. The estimation of amylase also provides a check on the information derived from the measurement of trypsin and guards against the possible misinterpretation of isolated defects in the secretion, or failure of activation, of the precursors of the proteolytic enzymes.

The authors wish to thank Miss C. Axelson and Mr A. D. Clarke for expert technical assistance. A research grant from the Cystic Fibrosis Research Trust to K.G.W. and a grant for equipment from the Board of Governors, United Sheffield Hospitals to D.M.G. are gratefully acknowledged.

\section{References}

Ammann, R. W., Tagwercher, E., Kashiwagi, H., and Rosenmund, H. (1968). Diagnostic value of fecal chymotrypsin and trypsin assessment for detection of pancreatic disease. Amer. J. dig. Dis., 13, 123-146.

Ben Abdeljlil, A., and Desnuelle, P. (1964). Sur l'adaption des enzymes exocrines du pancréas à la composition du régime. Biochim. biophys. Acta (Amst.), 81, 136-149.

Bernfeld, P., and Studer-Pécha, H. (1947). Sur les enzymes amylolytiques. (II). L'affinité entre enzyme et substratum pour quelques $\alpha$-amylases. Helv. chim. Acta., 30, 1904-1910.

Burton, P., Evans, D. G., Harper, A. A., Howat, H. T., Oleesky, S., Scott, J. E., and Varley, H. (1960). A test of pancreatic function in man based on the analysis of duodenal contents after administration of secretin and pancreozymin. Gut, 1,111-124.

Choi, H. J., Goldstein, F., Wirts, C. W., and Menduke, H. (1967). Normal duodenal trypsin values in response to secretinpancreozymin stimulation with preliminary data in patients with pancreatic disease. Gastroenterology, 53, 397-402.
Creutzfeldt, W. (1964). Funktionsdiagnostik bei Erkrankungen des exokrinen Pankreas. Vehr. dtsch. Ges. inn. Med., 70, 781-801.

Diamond, J. S., Siegel, S. A., Gall, M. B., and Karlen, S. (1939). The use of secretin as a clinical test of pancreatic function. Amer. J. dig. Dis., 6, 366-372.

Gibbs, G. E. (1950). Secretin tests with bilumen gastroduodenal drainage in infants and children. Pediatrics, 5, 941-946.

Goldberg, D. M., Campbell, R., and Roy, A. D. (1969). Studies on the binding of trypsin and chymotrypsin by human intestinal mucosa. Scand. J. Gastroent., 4, 217-226.

Gowenlock, A. H. (1953). The estimation of tryptic activity in duodenal contents. Biochem. J., 53, 274-277.

Grossman, M. I., Greengard, H., and Ivy, A. C. (1942). The effect of dietary composition on pancreatic enzymes. Amer. $J$. Physiol., 138, 676-682.

Guth, P. H., Komarov, S. A., Shay, H., and Style, C. Z. (1956) Relationship between protein nitrogen, proteolytic, amylolytic and lipolytic enzymes in canine pancreatic juice obtained under various conditions of stimulation. Amer. J. Physiol., 187, 207-223.

Haver back, B. J., Dyce, B. J., Gutentag, P. J., and Montgomery, D. W. (1963). Measurement of trypsin and chymotrypsin in stool. A diagnostic test for pancreatic exocrine insufficiency. Gastroenterology, 44, 588-597.

Hershfield, N. B., Lind, J. F., and Hildes, J. A. (1968) Clinical correlations with pancreatic function tests. Canad. med. Ass. J., 98, 185-188.

Lagerlöf, H. (1939). The secretin test of pancreatic function. Quart. J. Med., 8, 115-126.

Lagerlöf, H. (1942). Pancreatic function and pancreatic disease studied by means of secretin. Acta med scand. Suppl. 128.

Ribet, A., Pascal, J.-P., and Vaysse, N. (1968). Recherche de la capacité enzymatique maxima du pancréas exocrine humain normal sous perfusion continue de sécrétine et de pancréozymine. Biol. et Gastroent., 2, 163-170.

Rick, W. (1965). Zur Pathologie der Enzymsekretion des Pankreas. Acta Gastro-ent. belg., 28, 389-400.

Rothman, S. S. (1967). 'Non-Parallel transport' of enzyme protein by the pancreas. Nature (Lond.), 213, 460-462

Sarles, H., Figarella, C., Prezelin, G., and Souville, C. (1966). Comportement différent de la lipase, de l'amylase, et des enzymes protéolytiques pancréatiques apres différents modes d'excitation du pancréas humain. Bull. Soc. Chim. biol. (Paris), 48, 951-957.

Siegel, S. (1956). Nonparametric Statistics for the Behavioural Sciences. McGraw-Hill, New York.

Wormsley, K. G. (1968). Response to secretin in man. Gastroenterology, 54, 197-209.

Worning, H., and Müllertz, S. (1966). pH and pancreatic enzymes in the human duodenum during digestion of a standard meal. Scand. J. Gastroent., 1, 268-283.

Zieve, L., Silvis, S. E., Mulford, B., and Blackwood, W. D. (1966). Secretion of pancreatic enzymes. I. Response to secretin and pancreozymin. Amer. J. dig. Dis., 11, 671-684. 